\title{
Determinants of female employees' job performance in Malaysia
}

\author{
Siti Nor Adawiyah Azzahra Kamaruddin ${ }^{\mathrm{a}}$, Khatijah Omar ${ }^{\mathrm{b}}$, Jumadil Saputra ${ }^{\mathrm{a}^{*}}$, Elia Syarafina Abdul \\ Shakur ${ }^{\mathrm{b}}$, Nurul Aisyah Awanis A. Rahim ${ }^{\mathrm{a}}$ and Md Khairul Azwan Md Razali ${ }^{\mathrm{b}}$
}

${ }^{a}$ Faculty of Business, Economic, and Social Development, Universiti Malaysia Terengganu, 21030 Kuala Nerus, Terengganu, Malaysia ${ }^{b}$ Institute of Tropical Biodiversity and Sustainable Development, Universiti Malaysia Terengganu, 21030 Kuala Nerus, Terengganu, Malaysia

\section{H R O N I C L E}

\section{Article history:}

Received: June 27, 2020

Received in revised format:

August 102020

Accepted: August 10, 2020

Available online:

August 10, 2020

Keywords:

Female employees

Motivation

Time management

Organizational climate

Job performance

\section{A B S T R A C T}

Job performance becomes one of crucial issues and challenges faced by the organizations and it is related to employees' performance. In conjunction with the issue, this study investigates the determinants of job performance among female employees in Malaysia. Respondents involved in this study were composed of 320 female workers selected from manufacturing, education, health and hospitality sectors. The data was collected through self-administered questionnaires by using a five-point Likert scale. The study uses two common statistical analysis, including the descriptive and inferential statistics analyses by assisting statistical software, namely the Statistical Package for Social Science (SPSS-20). The outcome shows that motivation, organizational climate, and time management significantly influenced female employees' job performance. Also, the organizational climate was a determinant factor affecting female job performance in Malaysia. Thus, the finding of this study will assist female employees and employers in understanding the factors that could affect their performance in the organization.

(C) 2021 by the authors; licensee Growing Science, Canada

\section{Introduction}

Job performance becomes one of the crucial variables studied by past researchers. It is because of the issues and challenges facing by the organizations usually related to their business performance and employees' performance. Individual work performance is a problem not only for companies around the world but also drives a lot of studies in the areas of management, organizational and occupational psychology health (Koopmans et al., 2011). The success of an organization depends on the employees being able to perform their tasks, successfully. Human capital in the organization comprises all employees including male and female employees. There is no denying that female workers have contributed to today's economic growth. To achieve a competitive advantage, organizations rely on contribution from the internal employees. If more females work, especially those who are educated and skilled, it will contribute to the increase in national income as labor supply increases and productivity is expected to improve (Mohd \& Rameli, 2014).

Reaching an increase in the number of the female workforce is significant for the growth of the manufacturing and service sectors, as well as the health, hospitality, and education sectors (Kamaruddin et al., 2017). According to Evangeline and Thavakumar (2015), since Asian countries are full of human capital, special consideration and attention should be given to human resource management to increase organization job performance. The organization will not achieve success if female employees are not involved since female employees encounter as the most imperative element that determine the success of organization operation. Even though female workers in Malaysia encounter as essential contributors to organization and nation success, they are still faced with the negative perception on whether they can perform better in organization due to their multi responsibilities as a mother to care their children. Thus, it is worth if the female employees in the organization treated fairly and equally to comfort them so that they can perform better in the organization. These problems have motivated the researcher to conduct research related to the determining factor that could be affecting job performance among female employees in * Corresponding author. Tel.: +60176939109

E-mail address: jumadil.saputra@umt.edu.my (J. Saputra) 
Malaysia (Uddin, 2010). Based on the issues that occur among the female workforce in Malaysia, this study is carried out to define the effects of motivation, time management and organizational climate on job performance among female employees in Malaysia.

\section{Literature Review}

\subsection{Job Performance}

Employees' job performance is defined as the employees' abilities to use their skills and knowledge to create product and services, and the output from their effort contributes to the organization core (Evangeline \& Thavakumar, 2015). Generally, job performance is an outcome from the action that employees perform to complete their tasks and indirectly and directly leads to their organization success and failure. Research has found that various influences contributed to the employees' performance. Evangeline and Thavakumar (2015) found that factors such as compensation, performance-based evaluation practice and promotion have significantly correlated with employees' job performance in the Batticaloa District. Also, Boon et al. (2012) noted that the important predictors that related to job performance among employees are personality and work-family element. Organization factors such as organizational culture also straight affect worker performance (Resubun et al., 2013) and factors such as job involvement are also related to employees job performance (Hussain et al., 2012). The literature suggests that numerous factors can influence job performance. However, this study only concentrates on three (3) variables, which are motivation, time management and organizational climate that could impact on female employees' performance.

\subsection{Motivation}

Several studies have been conducted to investigate the correlation between motivation and employees job performance in general and found different results. Kamaruddin et al. (2017) found that motivation positively influence on female employees' job performance in Malaysia. Also, the findings by Salleh et al. (2011) revealed that there was no significant variance among motivation and employees' job performance, which indicates that employees' who have a low or high level of motivation demonstrate similar level of performance. Next, Aacha (2010) determined that motivation affects the performance of the primary school teacher and it also indicates that performance among teachers in the KimaanyaKyabakuza in Uganda were predicted by both intrinsic and extrinsic motivation.

\subsection{Organizational Climate}

The organizational climate is a worldwide concept and covers a wide sequence of climate characteristics which comprised five scopes such as innovation, responsibility, rewards, standards, and clarity (Putter, 2010). Putter (2010) attempted to survey the link between organizational performance and organizational climate and found that there was a positive relationship between variables among Tourism Hotels employees in Petra Region of Jordan. Also, Suandi et al. (2014) examined the influence of organizational climate, job stress on officer job performance at the North Zone State Education Department (JPN) in Malaysia. The study revealed that organizational climate and job stress significantly influenced officers' job performance at a moderate level, and Pearson Correlation showed that organizational climate had a significant influence on job performance at a moderate level. Jegajothi and Sudha (2015) stated that the workplace environment and employees' performance factors encouraged the employees' performance through workplace behavior, employees' productivity, job level, work commitment, job status, employee training, promotion and employee rewards.

\subsection{Time Management}

Time management is vital for all people without concerning whether the employed or unemployed. For those who work in the labor force, the management of time is crucial to ensure they can perform their tasks in the work timeline. Time management refers to the individual's abilities, activities and other actions that enable themselves to consume time efficiently (Pehlivan, 2013). Previous studies have predicted employees' performance using time management, showing that there is a positive relationship between time management and job satisfaction. Even though time management is essential, but still, some people ignore to manage their time accordingly. Through previous studies, a positive relationship has been proven to exist between time management and employee's performance. Kamaruddin et al. (2017) found time management factor has a significant correlation with female performance in Malaysia. Next, Abduljabbr et al. (2012) found that time planning and time approach with employee's performance has a positive relationship. However, Tehrani et al. (2013) indicated time management has a negative impact on job stress among sports employees. It portrays that the poor arrangement of time among employees' lead to employees' stress and directly will lower their task performance.

\subsection{Conceptual Framework}

Fig. 1 displays the proposed research framework. There are four variables used in this study which are motivation, organizational climate and time management as independent variables and job performance as dependent variables. 


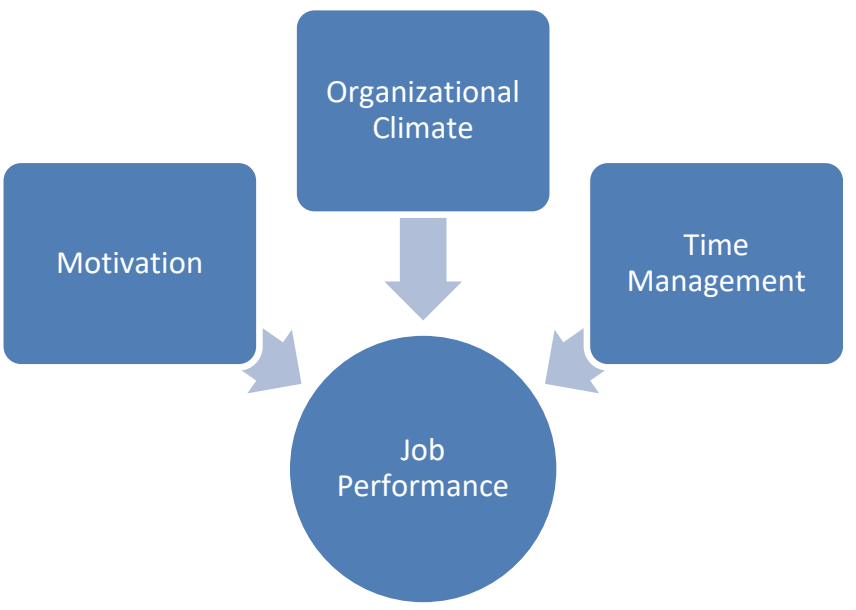

Fig.1. Research Framework

\section{Methodology}

This study is designed using a quantitative approach through a cross-sectional study. The sample in this study comprises female employees' in Malaysia occupied in four (4) sectors (manufacturing, education, health \& hospitality), and there were 320 female employees involved using a random sampling technique. These four (4) sectors were selected since they were dominated by the female employees' participation in labor force. An employees' survey questionnaire was used in this study to gain information from the female employees' perception towards determinants of job performance. The questionnaire included of five sections that are Part A (motivation), Part B (organizational climate), Part C (time management), Part D (job performance), and Part E (demographic profile). Five-point Likert scale range $(1=$ strongly disagree $),(2=$ disagree $),(3=$ neither disagree/neither agree), $(4=$ agree $)$, and $(5=$ strongly agree $)$ applied to rate employees' perception towards items ask to them in the questionnaire. The measurement has adapted from prior studies. Measurement for job performance has modified from Shaffril and Uli (2010), motivation (Javed \& Javed, 2013), organizational climate (Putter, 2010), and time management (Ngaji \& Malel, 2012).

\section{Results and Discussion}

Descriptive analysis and inferential analysis (regression analysis) are used to achieve the research objective.

\subsection{Demographic Profile}

The data cleaning process was done before conducting the data analysis. Data cleaning process aims to ensure that the data is good and clear for conducting analysis (descriptive analysis, reliability analysis, normality test \& regression analysis). Fig 2 demonstrates the demographic characteristics of the respondents.

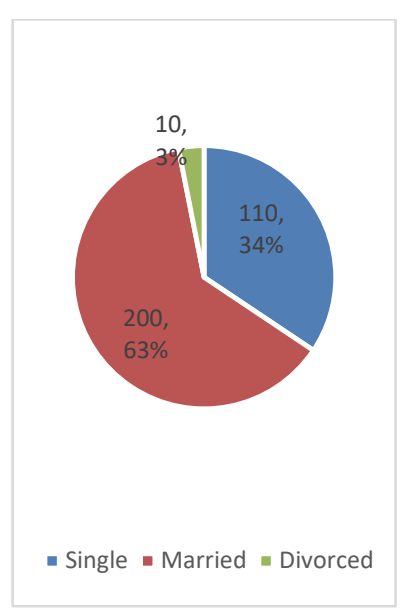

Gender

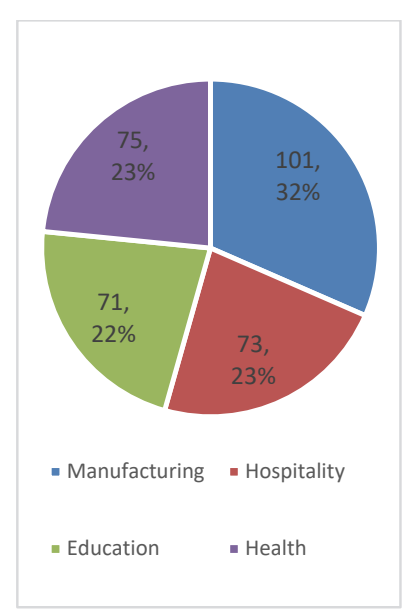

Sectors

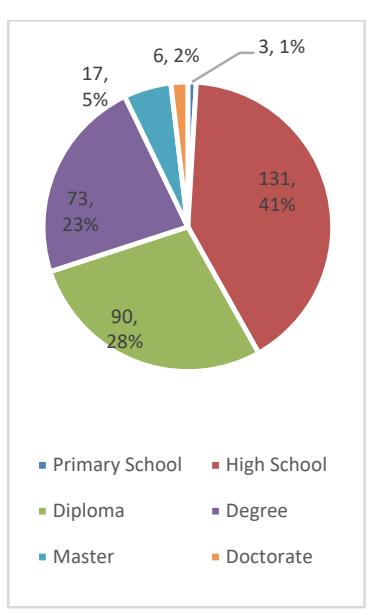

Education

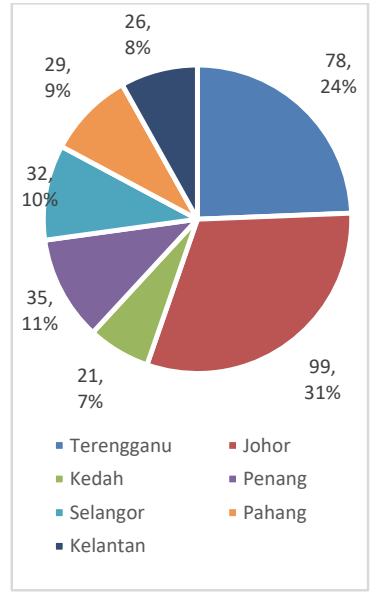

Locations 


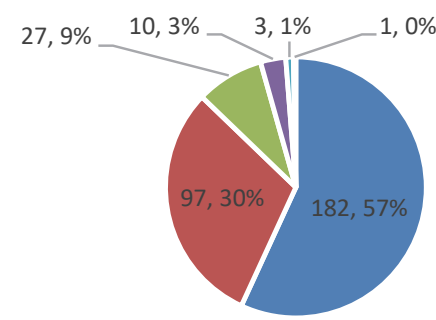

- Below RM2000 - RM2001 to RM4000

- RM4001 to RM6000 - RM6001 to RM8000

- RM8001 to RM10,000 - Above RM10,000

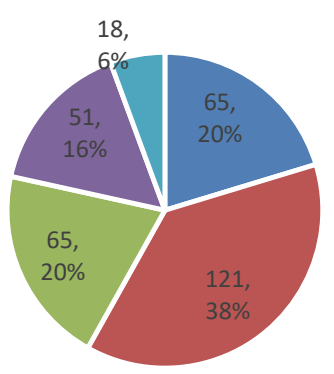

- Below 1 year . 1 to 5 years

-6 to 10 years $\quad-11$ to 20 years

- Above 20 years

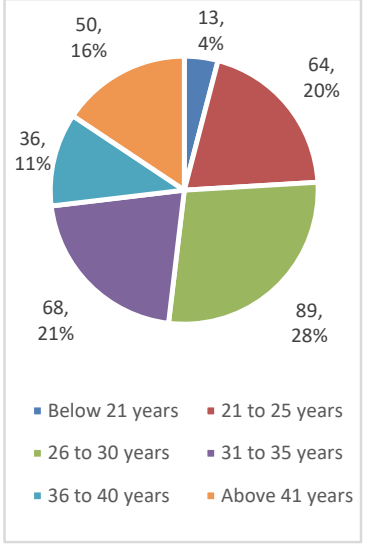

Age

Income

Job experience

Fig. 2. Personal characteristics of the participants

The figure shows the details of the information of the respondents (female employees') demographic profile. The purpose of this figure is to identify the background of the respondents who took part in this study. The majority of the female employees' who participated age from 26 years to 30 years old (27.8\%) followed by 31 years to 35 years old $(21.3 \%), 21$ years to 25 years old $(20.0 \%)$, above 41 years old $(15.6 \%), 36$ years to 40 years old $(11.3 \%)$ and below than 21 years $(4.1 \%)$. It portrays that the aged of female employees' in labor force involved in this study comprises the various level of age. Most of the female employees took part in this study is a married person (62.5\%), followed by a single (34.4\%) and divorced (3.1\%). It shows that female employees who work could carry multi responsibilities task as a mother, wife and as workers since majorityfemale employees' who took part in this study is a married person. Most of the female employees' took part in this study is held high school (SPM) certification (40.9\%) followed by diploma holder (28.1\%), degree (22.8\%), master (5.3\%), doctorate $(1.9 \%)$ and primary school only $0.9 \%$ only. It shows that most of the female employees who enter the labor force achieve the minimum work required. Majority of the respondents' income level is below than RM2000 (56.9\%), followed by RM2001RM4000 (30.3\%), RM4001-RM6000 (8.4\%), RM8001-RM10,000 (0.9\%), and more than RM10000 (0.3\%). It shows that the income level of the respondents is compatible with their education level. The figure also shows that the majority of the female employees take part in this study were involved in the manufacturing sectors $(31.6 \%)$ followed by health sectors $(23.4 \%)$, hospitality (22.8\%), and education sector (22.2\%) and the majority of them work in Johor (30.9\%), Terengganu (24.4\%), Penang (10.9\%), Selangor (10.0\%), Pahang (9.1\%), Kelantan (8.1\%) and Kedah (6.6\%). It indicated that the respondents could represent the female employee's perception towards determinants of job performance in Malaysia since the background of the respondents comes from peninsular of Malaysia.

\subsection{Normality Test}

Normality test was conducted out in this study to make sure whether the data is normally distributed or not. Descriptive statistics (skewness-kurtosis) were applied to test the normality of the data for this study. Table 1 indicates that data distribution in this study considered as normal. It can be seen from the values of the skewness and kurtosis were ranged from -0.148 to 0.069 . The data are considered normal when the value of skewness and kurtosis is a range between -1 and +1 (Chua, 2006). The results of the normality displays that the value of S-K for motivation, organizational climate, time management and job performance were less than 1.

Table 1

The Results of Descriptive Statistics $(\mathrm{N}=320)$

\begin{tabular}{|c|c|c|c|c|c|}
\hline \multirow{2}{*}{ Variables } & \multirow{2}{*}{$\begin{array}{c}\text { Mean } \\
\text { Statistics }\end{array}$} & \multicolumn{2}{|c|}{ Skewness } & \multicolumn{2}{|c|}{ Kurtosis } \\
\hline & & Statistic & Std. Error & Statistic & Std. Error \\
\hline Motivation & 4.15 & -0.304 & 0.136 & 0.069 & 0.272 \\
\hline Organizational Climate & 3.92 & -0.148 & 0.136 & 0.596 & 0.272 \\
\hline Time Management & 3.70 & -0.512 & 0.136 & 0.992 & 0.272 \\
\hline Job Performance & 3.89 & -0.145 & 0.136 & 0.819 & 0.272 \\
\hline
\end{tabular}

\subsection{Validity and Reliability Analyses}

The questionnaire in this study is also tested to ensure that the instruments meet the requirement of validity and reliability. This study examined the validity of the questions in the surveys throughout the set of the questionnaires. We have distributed to 10 female employees from education sectors. The purpose was to gain their understanding of the questions. Then, the questionnaires were reviewed by the management expert lecturer form the university. Next, the traditional methods were applied to test the reliability of the measurement scale namely as Cronbach's Alpha. DeVellis (2003) stated that the values of Cronbach's Alpha categorized as acceptable if the alpha value is above 0.70 , good 0.80 and very good 0.90 . Table 3 shows that measurements variables for job performance, motivation, organizational climate and time management were good and reliable to use since the Cronbach's Alpha value above 0.80 . 
Table 2

The Results of Reliability Testing

\begin{tabular}{ccc}
\hline Variables & Cronbach's Alpha & N of Items \\
\hline Job Performance & 0.853 & 8 \\
Motivation & 0.862 & 10 \\
Organizational Climate & 0.871 & 12 \\
Time Management & 0.832 & 5 \\
\hline
\end{tabular}

\subsection{Regression Analysis (Single Equation Model)}

Table 3 indicates the result of the statistical analysis of the model summary. The result demonstrates that time management, motivation, and organizational climate could explain their effect on job performance by $44.9 \%$. It means that there are $55.1 \%$ explained by other variables that could affect job performance.

Table 3

The Result of Model Summary (Coefficient Determination)

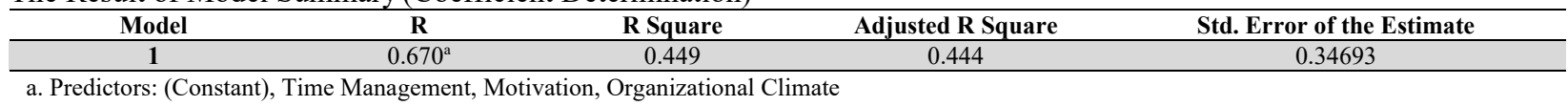

b. Dependent Variable: Job Performance

Table 4 demonstrates the analysis of variance. The ANOVA test displays the significance level of the model (Pallant, 2013) and also shows the goodness of the model fitness. Table 4 shows that generally, the model fitness of this study can be concluded that is significant with the $f$-value $=85.847, p<0.05$.

Table 4

The Results of Analysis of Variance (ANOVA ${ }^{a}$ )

\begin{tabular}{ccccc}
\hline Model & Sum of Squares & df & Mean Square & F \\
\hline Regression & 30.998 & 3 & 10.333 & $0.000^{\mathrm{b}}$ \\
Residual & 38.034 & 316 & 0.120 \\
\hline Total & 69.031 & 319 & \\
\hline
\end{tabular}

a. Dependent Variable: Job Performance

b. Predictors: (Constant), Time Management, Motivation, Organizational Climate

\subsection{Hypothesis Testing}

Table 5 indicates the findings of hypotheses testing. The finding displays that the organizational climate has the highest degree of significance in determining job performance among female employees' in Malaysia. The Beta Unstandardized Coefficients of organizational climate is 0.315 , t statistics value is 5.929 and $p$-value $<0.001$. It followed by time management factors with the Beta Unstandardized Coefficients is 0.261 , $\mathrm{t}$ statistics value of 4.6645 and $\mathrm{p}$-value $<0.001$ and motivation factors influence on female employees' job performance in Malaysia with the Beta Unstandardized Coefficients $=0.162$, $\mathrm{t}$ statistics vale 3.596 and the p-value is $<0.001$. Also, organizational climate, motivation and time management were found to be directly and positively influence female employees' job performance in Malaysia (see regression slope $=.315, .162 \& .261$ ). Regression slope shows that when the independent variable is high, then the dependent would also be high. Thus, if organizational climate, time management, and motivation changes as much as $1 \%$ respectively, it will give effect to female employees' job performance in Malaysia by $31.5 \%, 16.2 \%$ and $26.1 \%$.

Table 5

The Results of Hypothesis Testing

\begin{tabular}{|c|c|c|c|c|c|}
\hline \multirow{2}{*}{ Model } & \multicolumn{2}{|c|}{ Unstandardized Coefficients } & \multirow{2}{*}{$\frac{\text { Standardized Coefficients }}{\text { Beta }}$} & \multirow{2}{*}{$t$} & \multirow{2}{*}{ Sig. } \\
\hline & $\mathrm{B}$ & Std. Error & & & \\
\hline (Constant) & 1.014 & 0.191 & & 5.311 & 0.000 \\
\hline Motivation & 0.162 & 0.045 & 0.173 & 3.596 & 0.000 \\
\hline Organizational Climate & 0.315 & 0.053 & 0.329 & 5.929 & 0.000 \\
\hline Time Management & 0.261 & 0.040 & 0.324 & 4.645 & 0.000 \\
\hline
\end{tabular}

a. Dependent Variable: Job Performance

Table 5 demonstrates the results of hypothesis testing. The current study found that organizational climate, time management and motivation had a significant positive influence on female employees' job performance in Malaysia. Thus, the objective of this study achieved by finding that organizational climate, motivation and time management had significant effects on the female employees' job performance in Malaysia. Also, the organizational climate is a determinant factor affecting female job performance in Malaysia. Selamat et al. (2013) found that organizational climate elements significantly affected teachers' job performance. Next, Kamaruddin et al. (2017) found that factors such as motivation and time management had positive and significant effect on female employees' performance in Malaysia. It concluded that female employees' in Malaysia could perform their task and job excellently if factors such as organizational climate were well prepared and considered in their organization. Motivation and time management are also crucial to motivate female employees' for increasing their job performance. It is because of high motivation and well organizing time for work which can be reduced the employees stress at the workplace, and female employees can finish their works within the work timeline. 


\section{Conclusion}

This study has successfully investigated the determinants factor affecting female job performance in Malaysia. There are several studies on other factors that influence job performance. Three (3) determinants that might affect female employees' job performance in Malaysia have been focused in this study. As expected, the determinants such as organizational climate, motivation and time management have maintained positive and significant effects on female performance in Malaysia. The findings of this study would enrich the people, employees' and employer understanding the role of the organizational climate, time management and motivation in the female job performance. Understanding the determinants of job performance among the female employees' will assist employers and employees' itself to plan their work efficiently.

\section{References}

Aacha, M. (2010). Motivation and the performance of primary school teachers in Uganda: A case of Kimaanya-Kyabakuza Division, Masaka District. Kampala, Uganda: Makerere University.

Abduljabbr, A. N., Mahdi, O. R., and Almsafir, M. K. (2012). Relationship between time management and job performance empirical study in Malaysia private university. Journal of Advanced Social Research, 2(10), 427-438.

Boon, L. K., Fern, Y. S., Sze, C. C., \& Yean, O. K. (2012). Factors affecting individual job performance. In the International Conference on Management, Economics and Finance, (pp. 661-676). Kuching, Sarawak, Malaysia.

Chua, Y. P. (2006). Asas statistik penyelidikan. Selangor, Malaysia: Mcgraw-Hill.

Devellis, R. F. (2016). Scale development theory and applications. Thousand Oaks, USA: SAGE Publications.

Evangeline, S. J., \& Thavakumar, D. (2015). The Impact of Compensation, Performance Evaluation and Promotion Practices on Employees' Job performance - A study on Insurance Companies in Batticaloa District. 4th Annual International Research Conference, (pp. 59-67).

Hussain, A., Sardar, S., Usman , M., \& Ali, A. (2012). Factors affecting the job performance: In case of Pakistani banking sector. Elixir International Journal, 47, 8726-8730.

Javed, L., \& Javed, N. (2013). An empirical study on the factors that affects employee motivation and their relationship with job performance. International Journal of Management Sciences, 1(4), 114-124.

Jegajothi, C., \& Sudha, D. S. (2015). A study on organizational climate and employee performance. Indian Journal of Applied Research, 5(4), 347-349.

Kamaruddin, S. N., Khatijah , O., Muda , M. S., Saputra , J., \& Ismail, S. A. (2017). Motivation, time management and work performance among female workers in Malaysia. International Journal of Advanced and Applied Sciences, 4(12), 273280.

Koopmans, L., Bernaards , C. M., Hildebrandt, V. H., Schaufeli , W. B., Vet, H. C., \& Beek, A. J. (2011). Conceptual frameworks of individual work performance: A systematic review. Journal of Occupational and Environmental Medicine, 53(8), 856-866.

Mohd, A. S., \& Rameli, M. F. (2014). Fenomena Kekurangan tenaga kerja wanita berpendidikan dan berkemahiran di Malaysia. In the Persidangan Kebangsaan Ekonomi Malaysia ke-9 (PERKEM ke-9), (pp. 269-277). Kuala Terengganu, Terengganu, Malaysia.

Njagi, L. K., \& Malel, J. (2012). Time management and job performance in selected parastatals in Kenya. Australian Journal of Business and Management Research, 2(5), 19-29.

Pallant, J. (2013). SPSS survival manual: A step by step guide to data analysis using SPSS version 1. New York, USA: McGraw-Hill Education.

Pehlivan, A. (2013). The effect of the time management skills of students taking a financial accounting course on their course grades and grade point averages. International Journal of Business and Social Science, 4(5), 196-203.

Resubun, Y., Djazuli, A., \& Lecturer , M. (2013). Factors affecting employee performance in regional owned enterprises Papua Province-Indonesia. Interdisciplinary Journal of Contemporary Research in Business, 5(6), 755-767.

Salleh, F., Dzulkifli , Z., Abdullah, W. A., \& Yaakob, N. H. (2011). The effect of motivation on job performance of state government employees in Malaysia. International Journal of Humanities and Social Science, 1(4), 147-154.

Shaffril, H. A., \& Uli, J. (2010). The influence of socio-demographic factors on work performance among employees of government agriculture agencies in Malaysia. Journal of International Social Research, 3(10), 459-469.

Suandi, T., Ismail, I., and Othman, Z. (2014). Relationship Between Organizational Climate, Job Stress And Job Performance Officer At State Education Department. International Journal of Education \& Literacy Studies, 2(1), 18-28.

Tehrani, H., Rakhshani , T., Zadeh, D. S., Hosseini, S. M., \& Bagheriyan, S. (2013). Analyzing the relationship between job stress to mental health, personality type and stressful life events of the nurses occupied in Tehran 115 emergency. Iranian Red Crescent Medical Journal, 15(3), 272-273.

Uddin, N. B. (2010). Faktor penentu penyertaan wanita dalam pasaran buruh. In the Persidangan Kebangsaan Ekonomi Malaysia ke V (PERKEM V), Inovasi dan Pertumbuhan Ekonomi, (pp. 28-38). Port Dickson, Negeri Sembilan.

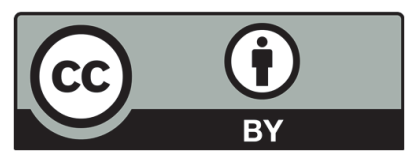

(C) 2020 by the authors; licensee Growing Science, Canada. This is an open access article distributed under the terms and conditions of the Creative Commons Attribution (CC-BY) license (http://creativecommons.org/licenses/by/4.0/). 